[in Russian].

Kozina, A.V. (2015). Motyvatsiya navchannya doroslykh u konteksti teoriyi samodeterminatsiyi [Motivation of adult learning in the context of the theory of self-determination]. Molodyy vchenyy - Young scientist, 2 (17). [in Ukrainian].

Kulyutkin, YU.N. \& Sukhobskaya, G.S. (red.). (1972). Motivatsiya poznavatel'noy deyatel'nosti uchashchikhsya [Motivation of students' cognitive activity] L.: NII OOV. [in Russian].

Maksymenko, S.D. (2007). Struktura osobystosti [Personality structure]. Praktychna psykholohiya i sotsial'na robota - Practical psychology and social work,1. 413. [in Ukrainian].

Psykholohichnyy slovnyk [Psychological dictionary]. (1982) (red. V.Y. Voytko). K.: Vyshcha shkola - High school. [in Ukrainian].

Romenets, V.A., Manoha, I.P. (2003). Istoriya psykholohiyi XX stolittya [History of psychology of the twentieth century]: navch. posibnyk. K.: Lybid'. [in Ukrainian].

Chirkov, V.I. (1991). Motivatsiya uchebnoy deyatel'nosti [Motivation of educational activity]. Yaroslavl': YarGU. [in Russian].

Удк 347.7

DOI: https://doi.org/10.35387/od.2(18).2020.22-33

Авшенюк Наталія Миколаївна-доктор педагогічних наук, старший науковий співробітник, завідувач відділу зарубіжних систем педагогічної освіти і освіти дорослих Інституту педагогічної освіти і освіти дорослих імені Івана Зязюна НАПН України

ORCID iD: https://orcid.org/0000-0003-1012-005X

E-mail: nataliya.avshenyuk@gmail.com

\title{
ПОЛІТИЧНІ ВЕКТОРИ ЮНЕСКО В РОЗВИТКУ ОСВІТИ ДОРОСЛИХ
}

\begin{abstract}
Анотація. В оглядовій статті на підставі інтегрованого аналізу ключових документів ЮНЕСКО (Рекомендацій Міжнародних конфререниії з освіти дорослих CONFINTEA (1985 p., 1997 p., 2003 р., 2009 р.), Глобальних звітів з освіти дорослих (2009 р., 2013 p., 2016 p., 2019 р.)) окреслено вплив доказових досліджень освітньої політики в обгрунтуванні напрямів розвитку освітньої політики в галузі навчання й освіти дорослих у світовому освітньому просторі наприкінці $X X-$ початку XXI cm. Встановлено, що у визначеному періоді необхідність розвитку освіти дорослих обумовлена динамікою соціального і науковотехнічного прогресу; змінами в змісті й характері праці й суспільної діяльності людей; збільшенням вільного часу $і$ можливостей його раціонального використання; запитами ринку праці, головними вимогами, якого стають підвищення компетентності й профресіоналізму фахівия. Залучення дорослої людини до різних форм освітньої діяльності
\end{abstract}


впродовж життя сприяє не лише задоволенню власних потреб, а й самореалізації у вільному виборі місия, часу, траєкторії удосконалення. Доведено, що з 70-х рр. в XX cm. й донині ЮНЕСКО відіграє ключову роль у формулюванні та дисемінації в сорері освітньої політики концепції навчання впродовж життя. Концепція, по суті, передбачає реструктуризацію існуючої системи освіти та використання освітнього потенціалу навчання дорослих поза традиційною освітньою системою $з$ метою впливу на розвиток різних соціальних груп та індивідуальний розвиток кожної людини. У світі накопичено значний конструктивний досвід розвитку теорії і практики освіти дорослих, який акумулюється, поширюється й впроваджується завдяки діяльності міжнародних організацій глобального масштабу, зокрема ЮНЕСКО. Ця міжнародна організація генерує ідеї й вибудовує освітню політику, що грунтується на надійних статистичних даних і результатах глобальних емпіричних досліджень.

Ключові слова: безперервна освіта впродовж життя, освіта дорослих, міжнародна освітня політика, критична педагогіка, ЮНЕСКО, Міжнародна конфреренція з освіти дорослих CONFINTEA

Avshenyuk Nataliya - Doctor of Science in Education, Senior Staff Research, Head of the Foreign Pedagogical and Adult Education Department, Ivan Ziaziun Institute of Pedagogical and Adult Education of the NAES of Ukraine

ORCID iD: https://orcid.org/0000-0003-1012-005X

E-mail: nataliya.avshenyuk@gmail.com

\section{UNESCO POLITICAL VECTORS IN ADULT EDUCATION DEVELOPMENT}

Abstract. The review article is based on an integrated analysis of key UNESCO documents (Recommendations of the International Conference on Adult Education CONFINTEA (1985, 1997, 2003, 2009), Global Reports on Adult Learning and Education (2009, 2013, 2016, 2019) that outlines the impact of evidence-based research on educational policy in supporting the development of educational policy in adult learning in the global educational environment at the end of the XX and at the beginning of the XXI century. It is found that the development of adult education is necessary due to the dynamics of social, scientific and technological improvement; changes in the content and nature of work and social activities of people; increased free time and opportunities for its effective use; labor market demands, the main requirements of which are to increase the competence and skills of the professional. Adult involvement in lifelong learning not only encourages meeting own needs, but also ensures self-fulfillment to a free choice of a place, time and a pathway of improvement. It is proved that since the 1970s up to now UNESCO has played a key role in shaping and disseminating the concept of lifelong learning in 
education policy. The concept, in essence, involves the restructuring of the existing education system and use of educational perspectives of adults externally the traditional education system in order to influence the development of different social groups and individual development of each person. The world has accumulated considerable meaningful experience in the development of the theory and practice of adult education, which is accumulated, disseminated and implemented through the activities of international organizations on a global scale, including UNESCO. This international organization generates ideas and builds educational policies that are based on reliable statistics and the results of global empirical research.

Key words: lifelong learning, adult education, international educational policy, critical pedagogy, UNESCO, CONFINTEA

Постановка проблеми, їі актуальність. На початку XXI ст. незважаючи на всесвітньо визнану економічну доцільність безперервного навчання дорослого населення, ЮНЕСКО $\epsilon$ однією 3 небагатьох міжнародних організацій-сподвижниць розвитку демократичних програм освіти дорослих. У глобальному освітньому просторі ЮНЕСКО - це єдина міжнародна організація, в якій бере участь уся світова освітянська спільнота, на противагу ОЕСР та Світовому банку, що об'єднують, переважно, індустріально розвинені країни світу, і опікуються значно вужчим колом освітніх проблем. 31945 р. діяльність ЮНЕСКО в галузі освіти впродовж життя спрямована на формування нового міжнародного порядку, утверджуючи головну роль освіти в становленні й розвитку особистості людини і зміцненні її соціальних зв'язків.

Відправною точкою в історії становлення міжнародної освітньої політики ЮНЕСКО щодо освіти дорослих вважають ухвалення у 1976 р. «Рекомендацій про розвиток освіти дорослих» (далі-Рекомендації) на Генеральній Конфреренції ООН з питань освіти, науки і культури в м. Найробі (UNESCO, 1976). Саме в цьому документі на всесвітній загал обґрунтовувалося поняття «освіта дорослих», сфрормулювалися ключові постулати її становлення та визначалися основоположні принципи розвитку. Нині - це загальноцитовані, класичні твердження, які широко використовуються науковцями й практиками в галузі освіти дорослих i формують теоретичні засади цієї галузі освіти. Вивчення змісту цього документу засвідчує, що освіта дорослих стає невід'ємною частиною вибудуваної у XX ст. системи освіти відповідно до принципів ї̈ безперервності впродовж життя. У Рекомендаціях уперше наголошується, зокрема на відповідальності країн за визнання освіти дорослих особливим оптимізуючим компонентом всієї системи освіти, а також за сприяння її становлення як елемента соціокультурного й економічного розвитку.

Проте, ще у далекому 1949 р. в данському м. Хельсінгер ЮНЕСКО було започатковано Міжнародну конференцію 3 освіти дорослих (CONFINTEA) (далі - Конференція), яка з того часу проводиться один раз 
на 12 років: 1960 р. (м. Монреаль, Канада), 1972 р. (м. Токіо, Японія), 1985 р. (м. Париж, Франція), 1997 р. (м. Гамбург, Німеччина), 2009 р. (м. Белем, Бразилія). Розглянемо детальніше еволюцію стратегічних ініціатив ЮНЕСКО у розвиткові освітньої політики в галузі навчання й освіти дорослих крізь призму рекомендацій, затверджених у резолюціях зазначених Конференцій.

Наше дослідження показує, що у другій половині 80-x-середині 90-х рp. XX ст. ученими й управлінцями в галузі освіти дорослих досліджувалися складні проблеми методологічного порядку; у процесі загальнотеоретичного розроблення проблематики закладалися концептуальні основи, вивчався увесь спектр соціальних, економічних, політичних, організаційних, адміністративних умов ї̈ реалізації. Саме у 1985 р. у Парижі (Франція) відбулася Четверта Міжнародна конференція 3 освіти дорослих (CONFINTEA IV), у резолюції якої зазначалося про суттєві зміни в її розвитку, а саме: розширення структурних зв'язків (на основі вертикальної і горизонтальної інтеграції фрорм освіти) між освітою дорослих й іншими компонентами систем безперервної освіти; загальне прагнення до міжнародного співробітництва на основі чітко визначених пріоритетних цілей; створення нових дослідницьких центрів і міжнародних організацій (Четвертая, 1986).

П'ята Міжнародна конференція з освіти дорослих (CONFINTEA V) в Гамбурзі (Німеччина, 1997 р.), в якій взяли участь міністри освіти, культури й інформації зі 140 країн світу, а також керівництво ООН і ЮНЕСКО, стала поворотним пунктом в історії міжнародного визнання важливості освіти дорослих, як унікального способу забезпечення сталого розвитку суспільств різних рівнів організації та орієнтації. За результатами Конференції учасниками було напрацьовано й затверджено «Гамбурзьку декларацію про освіту дорослих», в якій вперше наголошувалося на необхідності: 1) взаємодоповнюваності змісту освіти різних рівнів і ступенів в умовах безперервності освіти впродовж життя; 2) гарантування державою права дорослій людині на навчання у зручній для неї формі; 3) розроблення державних і недержавних соціальних програм з розвитку освіти дорослих (UIE, 1997).

Наступним внеском у розвиток міжнародних стратегій у галузі освіти дорослих стала Шоста Міжнародна конференція (CONFINTEA VI), що відбулася у грудні 2009 р. у м. Белем (Бразилія). Представниками 144 країн-учасниць було затверджено «Белемську рамку дій», в якій основна увага, з поміж інших актуальних проблем різноманіття форм i напрямів освіти дорослих, приділялася визнанню неформальної освіти як офріційної форми отримання освіти впродовж життя (UIL, 2009). Це зібрання надало імпульс вивченню шляхів і засобів для вирішення найважливіших питань навчання дорослих людей (поширення грамотності, рівний доступ до базової й безперервної освіти впродовж життя), які розглядаються ключовими у вирішенні глобальних проблем людства, а саме: утвердження 
демократії, миру і прав людини, збереження різноманітності, забезпечення освіти для всіх та освіти для стійкого розвитку суспільства, урегулювання конфрліктів, розвиток трудових ресурсів.

Як бачимо, в умовах сьогодення, Конференція $\epsilon$ важливою платформою на міжнародному рівні для політичного діалогу і прийняття нових зобов'язань у галузі освіти дорослих, а саме: поширення грамотності, утвердження неформальної освіти та навчання, офріційного визнання набутих упродовж життя кваліфікацій, зокрема в межах неформальної й інформальної освіти.

Аналіз останніх досліджень і публікацій. На підставі метатеоретичного аналізу (meta-theoretical analysis) фундаментальних праць 3 критичної педагогіки (Ю. Габермас, Т. Маккарті, П. Макларен), а також за допомогою методу інтегрованого аналізу (Р. Торрако) наукової, науковопубліцистичної, навчально-методичної літератури з визначеної тематики, здійснено перегляд, вивчення, критичний аналіз та синтез репрезентативних літературних джерел на інтегрованій основі з метою генерування нових концептуальних ідей та перспективних напрямів дослідження встановленої проблеми.

Зазначимо, що критична теорія в найширшому сенсі не означає конкретної «теорії або цілісної дослідницької програми, а передбачає різноманіття (теоретичних) дискурсів», різних «за своїм походженням, змістом, спрямованістю». Серед таких дискурсів зазвичай називають психоаналіз, постструктуралізм, фемінізм, мультикультуралізм, дослідження расизму, етноцентризму, колоніалізму тощо. Критична теорія стверджує себе «як найбільш ефективний засіб викриття ідеологічних механізмів, що беруть участь у виробництві знання на «зворотній стороні» освіти» (Фурс, 2006). На думку П. Макларена, відповідно до критичної теорії, формальна освіта в сучасному суспільстві готує учнів до двох основних позицій: домінування або підлеглості в наявній соціальній структурі (Фрумин, 1998). Основна увага теоретиків критичної педагогіки (А. Грамші, П. Макларен, Д. Келлнер) звернена на створення умов для подолання таких стереотипів і формування суспільства на основі справедливих суспільних відносин. Відповідно до їхніх переконань, людина може трансформувати як себе, так і суспільні інститути, створюючи різні альтернативні структури (в тому числі альтернативні освітні інститути) (Kellner, 2003). Здійснене дослідження показало, що окреслені принципи критичної педагогіки у другій половині XX ст. стали основою для формування й утвердження формальної і неформальної освіти дорослого населення, зокрема й у політико-стратегічних дискурсах ЮНЕСКО.

Мета статті полягає в обґрунтуванні напрямів розвитку освітньої політики в галузі навчання й освіти дорослих у світовому освітньому просторі наприкінці $\mathrm{XX}$ - початку XXI ст. на підставі вивчення ключових документів ЮНЕСКО (Рекомендації Міжнародних конференції з освіти дорослих CONFINTEA (1985 р., 1997 р., 2003 р., 2009 р.), Глобальні звіти $з$ 
освіти дорослих (2009 р., 2013 р., 2016 р., 2019 р.)) з метою встановлення впливу технократичного підходу (technocratic thinking) та доказових досліджень освітньої політики (evidence-based policy research).

Виклад основного матеріалу дослідження. Сучасні стратегії світового прогресу ґрунтуються на принципах всебічного розвитку людського потенціалу, в яких роль освіти постійно зростає і стає домінуючою. Детермінанти розвитку суспільства на початку XXI ст. визначають умови, що актуалізують розроблення проблематики освіти дорослих, зокрема переосмислення ії базових орієнтирів, оскільки для нашого часу характерні надзвичайно активні процеси застарівання i, відповідно, оновлення знань. Такими умовами є: прийняття міжнародних правових актів про освіту дорослих; увиразнення глобального, регіональних і локальних освітніх просторів; формування позитивного іміджу освіти дорослих; визнання педагогічним співтовариством пріоритету гуманістичної освіти; розвиток концепції збалансованої освітньої політики; формування демократичних освітніх програм.

Ці процеси стимулюють опанування нових знань i компетентностей для забезпечення ефективної соціальної й професійної адаптації людини впродовж усього життя. Для вирішення поставлених перед суспільством завдань освіта дорослих має надати можливості, які дозволять людині: навчитися пізнавати, тобто забезпечити необхідним інструментарієм для розуміння, що відбувається в світі; навчитися робити, щоб продукувати в навколишньому середовищі потрібні зміни; навчитися сучасного життя, щоб брати участь у всіх видах діяльності і співпрацювати з іншими людьми; врешті, просто навчитися жити у диверсифікованому, швидкозмінному, багатозадачному світі. 3 цієї точки зору, освіта дорослих розглядається провідним чинником забезпечення національної безпеки в умовах загальносвітових глобалізаційних процесів, «ключем у XXI ст.» (International, 1997).

Зазначимо, що ЮНЕСКО як провідна організація ООН, що опікується проблемами освіти, допомагає країнам концептуалізувати й зреалізувати завдання модернізації систем освіти на всіх рівнях, зокрема й освіти дорослих у форматах формальної, неформальної й інфооммальної освіти. 3 метою надання допомоги всім країнам, що беруть участь у міжнародній спільній діяльності з гарантування якісної безперервної освіти своїм громадянам, ЮНЕСКО транслює досвід з планування й управління освітою; генерує ідеї й вибудовує освітню політику, що ґрунтується на надійних статистичних даних і результатах емпіричних досліджень; на міжнародному рівні формулює необхідність і стимулює діяльність щодо забезпечення освіті дорослих інклюзивного й інноваційного характеру, шляхом здійснення послідовної освітньої політики і узгодженого плану дій. Аналітичну обробку інформації, теоретичні дослідження, формулювання стратегічних планів міжнародної освітньої політики ЮНЕСКО здійснює в межах діяльності спеціально створених інституцій, зокрема Міжнародного 
інституту планування освіти та Інституту освіти впродовж життя (Организация, 2002).

Провідні аналітики зазначених інституцій (К. А. Торрес, К. МедельАнонуво, Р.Дес'ярдінс) утверджуються в думці, що усі країни-члени ЮНЕСКО постають перед двома дуже важливими викликами у розвитку освіти дорослих, а саме: 1) розвиток критичної маси наукових досліджень й наукового знання в галузі освіти дорослих та 2) розвиток ефективного управління й урядування в галузі освіти дорослих, які нерозривно пов'язані між собою (Medel-Anonuevo, 2011).

Така взаємозалежність пояснюється наявністю трьох основних напрямів наукової роботи у галузі освіти дорослих, а саме: 1) дослідженнявідкриття (scholarship of discovery) - базове дослідження фундаментальних основ френомену; 2) дослідження-інтеграція (scholarship of integration) передбачає використання мультидисциплінарних методів, міждисциплінарних теоретичних підходів, аналітичних даних, вивчення нормативних засад; 3) дослідження-втручання (scholarship of intervention) привертає до себе найбільше уваги урядовців і громадськості, оскільки має безпосередній вплив на формування освітньої політики та оцінювання її результатів. На думку експертів, для покращення порівнюваності великої кількості даних, що надходять з наукових інституцій різних країн світу, та посилення взаємовпливу теоретичних і практичних наукових розвідок, необхідно розвивати саме базові дослідження фундаментальних основ освіти дорослих (Medel-Anonuevo, 2011).

На наше переконання, не меншої уваги потребує вивчення феномену взаємозалежності наукових досліджень і формування ефективної освітньої політики, що в академічних колах зарубіжних країн отримав назву «доказові дослідження освітньої політики» («evidence-based policy research» by Medel-Anonuevo C., Torres C. A., Desjardins R. / «evidence-informed policy research» by Burns T., Schuller T.) (Burns, 2009). Зокрема, Т. Бернс та Т. Шуллер, спираючись на твердження представника критичної педагогіки П. Фрейре про нерозривність політики та освіти, трактують термін «доказові дослідження освітньої політики» як «чесне й відкрите використання поточних результатів надійних досліджень для прийняття політичних рішень та здійснення усвідомленого вибору 3-поміж можливих варіантів». Вони стверджують, що цей підхід відрізняється від традиційних наукових досліджень, оскільки спрямований на забезпечення прийняття «поінформованих» рішень, у той час як останні - здебільшого орієнтовані на розвиток теоретичних підходів та перевірку гіпотез (Burns, 2009).

Проте, осмислюючи процитоване визначення, вважаємо за необхідне зазначити, що обидва типи наукових досліджень є важливими для формування освітньої політики, адже базові фундаментальні дослідження наповнюють новим науковим знанням практикоорієтовані розвідки, розширюють їх методичний інструментарій та поглиблюють 
термінологічне поле, вивіряють надійність статистичних даних, що, як правило, унеможливлює дисоціацію емпірично-аналітичних компонентів досліджень від нормативно-творчих.

Як свідчить аналіз аналітичних, статистичних, довідкових і рекомендаційних документів ЮНЕСКО, ця організація в межах своєї діяльності завжди поєднувала обидва представлені типи дослідницької роботи, забезпечуючи лідерство у просуванні нових підходів до осмислення і опрацювання різних аспектів освіти дорослих. Адже на національному рівні будь-якої країни політичні діячі й чиновники зазвичай неохоче здійснюють спеціальні дослідження при формуванні освітньої політики, якщо вони не забезпечують їм політичних дивідендів (MedelAnonuevo, 2011). Проте, на думку переважної більшості науковців, сучасний стан наукових досліджень всієї галузі освіти, не лише у сфері освіти дорослих, характеризується нестачею критичних аналітичних розробок, що негативно впливає на їі якість. За цих обставин не можна ігнорувати посилення впливу інституцій громадянського суспільства та різних соціальних рухів на окреслення нових напрямів в освітній політиці навчання дорослого населення та їх практичну реалізацію.

Про піднесення ролі громадянського суспільства, а також визначення чітких завдань його діяльності в сфері освіти дорослих йдеться в підсумкових документах Шостої Міжнародної конференції $з$ освіти дорослих ЮНЕСКО (CONFINTEA VI) (UIL, 2010), Белемській рамці дій (2009 р.), Рекомендаціях ЮНЕСКО щодо освіти і навчання дорослих (2015р.), а також у Третій Всесвітній доповіді про освіту і навчання дорослих (2016р.) Інституту освіти впродовж життя ЮНЕСКО. Ці комплексні взаємодоповнюючі документи мають на меті допомогти міжнародній спільноті фахівців у розробці й реалізації довгострокової політики взаємодії державних і недержавних інституцій, а також громадянського суспільства щодо: 1) забезпечення відповідності програм освіти дорослих запитам різних категорій слухачів (нині цей процес активно діє у 68 \% країн-членів ЮНЕСКО); 2) ухвалення нових стратегій розвитку освіти дорослих (70 \% країн); 3) навчання грамотності й базових навичок (85 \% країн); 4) встановлення правових рамок визнання, сертифікації й акредитації програм неформального та інформального навчання (71\% країн); 5) збільшення видатків на фрінансування програм освіти дорослих (57 \% країн); 6) розвиток програм підготовки і підвищення кваліфікації викладачів та інструкторів для освіти дорослих (81 \% країн) (UIL, 2016).

Другим, не менш важливим, викликом $€$ розвиток ефективного управління й урядування в галузі освіти дорослих. Відповідно до Четвертої Всесвітньої доповіді про освіту і навчання дорослих (2019р.) Інституту освіти впродовж життя ЮНЕСКО поступ у сфері формування політики та управління освітою дорослих у 152 країнах-респондентах є обнадійливим, але недостатнім, оскільки деякі країни продовжують відставати. Так, дві третини країн, що надіслали свої звіти, повідомляють про помітний прогрес 
у цій сфрері, якого їм вдалося досягти з 2015 р., при цьому 44 країни (майже $30 \%$ взагалі не надали даних про зміни в політиці навчання й освіти дорослих після 2015 р., до яких належить 17 країн, розташованих в Азійсько-Тихоокеанському регіоні (47 \% цього регіону) (UIL, 2019).

Найважливішою проблемою в цих країнах, на нашу думку, $€$ недостатня розробленість й імплементація нового законодавства, що посилює ризики недоотримання множинних переваг від навчання й освіти дорослих як на державному, так і на громадському рівні. Зауважимо, що п'ять країн (3\%) повідомили про наявну з 2015 р. регресію в розвитку освітньої політики з навчання дорослих (UIL, 2019). Невтішною видається нам ситуація навколо визнання, валідації й акредитація неформального й інфрормального навчання, оскільки 66 \% країн звітували про найнижчий рівень розвитку цього напряму освітньої політики. Водночас, три чверті країн повідомили про значне вдосконалення системи управління освітою $\mathrm{i}$ навчанням дорослих. Управлінські структури, які допомагають реалізувати різні стратегії політики, помітно посилили застосування ефективних механізмів координації та опертя на міцні й чесні партнерські відносини між різними зацікавленими сторонами в системі освіти дорослих (UIL, 2019).

Як бачимо з опрацьованих національних звітів та всесвітніх доповідей, ЮНЕСКО прийняла грандіозний виклик - модерувати на міжнародному рівні діяльність багатьох зацікавлених осіб (урядові структури, громадські організації, адрагогічний персонал, дорослі учні) у розвитку освіти дорослих на різних етапах цього процесу. Однак ця справа не покладається виключно на ЮНЕСКО. Усі зацікавлені особи повинні нести власну відповідальність за розроблення та підтримку дієвих механізмів управління 3 метою досягнення цілей на всіх рівнях, від глобального до місцевого (від глобального до регіонального, від субрегіонального до національного, від субнаціонального до місцевого), а від місцевого до глобального.

Одним із найважливіших викликів, що стоять сьогодні перед ЮНЕСКО в освіті дорослих, $є$ фрормування ефективних структур, які сприяють демократичному управлінню (або управлінню знизу вгору), одночасно забезпечуючи узгодження поглядів для ефрективного спілкування усіх стейкголдерів та мобілізацію фрінансових і людських ресурсів для досягнення спільних цілей. Експерти відзначають недостатнє розуміння на глобальному рівні концепції навчання протягом усього життя, що сформульована ЮНЕСКО, оскільки вона видається віддаленою від місцевих реалій, а тому потребує попереднього узгодження й усвідомленого розуміння. Це вказує на першочергову необхідність посилення діяльності ЮНЕСКО в напрямі розвитку взаємодоповнюючих механізмів поширення й обговорення цієї та інших політичних концепцій, за допомогою яких може бути сформоване узгоджене їх розуміння шляхом систематичного діалогу та міжнародного обміну на постійній основі різнопланових національних звітів. Як мінімум, це передбачає: 
- посилення можливостей збору даних (якісних і кількісних);

- створення мереж та платформ для організації консультацій між ключовими стейкголдерами щодо переднього плану спільних обговорень на міжнародному рівні;

- забезпечення консультацій експертів на підставі вивчення синтезованих результатів досліджень та звітів у процесі міжнародних обговорень (Medel-Anonuevo, Torres, Desjardins, 2011).

$\mathrm{Ha}$ наш погляд, ключовим викликом щодо налагодження ефективного управління в галузі навчання та освіти дорослих на найближчу перспективу $є$ розроблення, підтримка й розвиток на постійній основі та на всіх рівня зазначених інструментів і механізмів.

Висновки і перспективи подальших досліджень. Отже, на підставі інтегрованого аналізу ключових документів ЮНЕСКО (Рекомендацій Міжнародних конференції з освіти дорослих CONFINTEA (1985 р., 1997 р., 2003 р., 2009 р.), Глобальних звітів з освіти дорослих (2009 р., 2013 р., 2016 р., 2019 р.)) окреслено вплив доказових досліджень освітньої політики в обґрунтуванні напрямів розвитку освітньої політики в галузі навчання й освіти дорослих у світовому освітньому просторі наприкінці XX-початку XXI ст. Встановлено, що у визначеному періоді необхідність розвитку освіти дорослих обумовлена динамікою соціального і науково-технічного прогресу; змінами в змісті й характері праці й суспільної діяльності людей; збільшенням вільного часу і можливостей його раціонального використання; запитами ринку праці, головними вимогами, якого стають підвищення компетентності й професіоналізму фахівця. Залучення дорослої людини до різних форм освітньої діяльності впродовж життя сприяє не лише задоволенню власних потреб, а й самореалізації у вільному виборі місця, часу, траєкторії удосконалення.

Доведено, що з 70-х років XX ст. й донині ЮНЕСКО відіграє ключову роль у формулюванні та дисемінації в сфері освітньої політики концепції навчання впродовж життя. Концепція, по суті, передбачає реструктуризацію існуючої системи освіти та використання освітнього потенціалу навчання дорослих поза традиційною освітньою системою 3 метою впливу на розвиток різних соціальних груп та індивідуальний розвиток кожної людини. У світі накопичено значний конструктивний досвід розвитку теорії і практики освіти дорослих, який акумулюється, поширюється й впроваджується завдяки діяльності міжнародних організацій глобального масштабу, зокрема ЮНЕСКО. Ця міжнародна організація генерує ідеї й вибудовує освітню політику, що ґрунтується на надійних статистичних даних і результатах глобальних емпіричних досліджень.

До перспективних напрямів подальших досліджень відносимо вивчення внеску міжнародних організацій глобального масштабу, зокрема Світового Банку, ОЕСР тощо у розбудову освіти і навчання дорослих. 


\section{Список використаних джерел}

Организация Объединенных Наций по вопросам образования, науки и культуры. (2002). Руководство Генеральной Конференции. Париж: ЮНЕСКО.

Фрумин, И. (1998). Вызов критической педагогики. Вопросы фрилософрии, $12,60$.

Фурс, В. (2006). Социальная философия в непопулярном изложении. Вильнюс: ЕГУ.

Четвертая международная конференция по образованию взрослых (Париж, 19-29 марта 1985 г.). (1986). Перспективы. Вопросы образования, 3, 116-136.

Burns, T., Schuller, T. (2009). Evidence-informed policy in education: New opportunities and challenges. In R. Desjardins, K. Rubenson (Eds.). Research of vs research for education policy: In an era of transnational education policy-making. Saarbrucken: VDM Verlag. 58-73.

International Conference on Adult Education. (Ed.). (1997). Fifth international conference on adult education, Hamburg, Germany, July 14-18, 1997: Final report. Paris: UNESCO.

Kellner, D. (2003). Toward a Critical Theory of Education. Journal Democracy \& Nature, 9 (1), 51-64

Medel-Anonuevo, C., Torres, C. A., Desjardins, R. (2011). CONFINTEA VI follow-up: the challenges of moving from rhetoric to action. International Review of Education, 57 (1-2), 1-8.

Torraco, R. (2005). Writing integrative literature reviews: Guidelines and examples. Human Resources Development Review, 4, 356.

Torres, C. A. (2015). From Hamburg to Belem: the limits of technocratic thinking in adult learning education. International Journal of Lifelong Education, 34 (1), 22-31.

UIE. (1997). Adult Education. The Hamburg Declaration. The agenda for the future. Hamburg: UNESCO Institute for Education.

UIL. (2009). CONFINTEA VI: Belem framework for action. Harnessing the power and potential of adult learning and education for a viable future (BFA). Hamburg: UNESCO Institute for Lifelong Leaning.

UIL. (2010). The Sixth International Conference on Adult Education (CONFINTEA VI) "Living and learning for a viable future: the power of adult learning»: Final Report. Hamburg: UNESCO Institute for Education.

UIL. (2016). The third Global Report on Adult Learning and Education (GRALE III). Hamburg: UNESCO Institute for Lifelong Learning.

UIL. (2019). 4 Global Report on Adult Learning and Education: Leave no One Behind: Participation, Equity and Inclusion. Hamburg: UNESCO Institute for for Lifelong Learning.

UNESCO. (1976). Recommendation on the development of adult education. Nairobi: UNESCO, 13. 


\section{References (translated and transliterated)}

Organizacija Ob'edinennyh Nacij po voprosam obrazovanija, nauki i kul'tury. (2002). Rukovodstvo General'noj Konferencii [Manual of the General Conference]. Parizh: JUNESKO. [in Russian].

Frumin, I. (1998). Vyzov kriticheskoj pedagogiki [The Challenge of Critical Pedagogy]. Voprosy filosofii [Problems of Philosophy], 12, 60. [in Russian].

Furs, V. (2006). Social'naja filosofija v nepopuljarnom izlozhenii [Social philosophy in an unpopular way]. Vil'njus: EGU. [in Russian].

Chetvertaja mezhdunarodnaja konferencija po obrazovaniju vzroslyh (Parizh, 19-29 marta 1985 g.) [Fourth International Conference on Adult Education (Paris, March 19-29, 1985)]. (1986). Perspektivy. Voprosy obrazovanija [Prospects. Education Issues], 3, 116-136. [in Russian].

Burns, T., Schuller, T. (2009). Evidence-informed policy in education: New opportunities and challenges. In R. Desjardins, K. Rubenson (Eds.), Research of vs research for education policy: In an era of transnational education policy-making, 58-73. Saarbrucken: VDM Verlag. [in English].

International Conference on Adult Education. (Ed.). (1997). Fifth international conference on adult education, Hamburg, Germany, July 14-18, 1997: Final report. Paris: UNESCO. [in English].

Kellner, D. (2003). Toward a Critical Theory of Education. Journal Democracy \& Nature, 9 (1), 51-64 [in English].

Medel-Anonuevo, C., Torres, C. A., Desjardins, R. (2011). CONFINTEA VI follow-up: the challenges of moving from rhetoric to action. International Review of Education, 57 (1-2), 1-8. [in English].

Torraco, R. (2005). Writing integrative literature reviews: Guidelines and examples. Human Resources Development Review, 4, 356. [in English].

Torres, C. A. (2015). From Hamburg to Belem: the limits of technocratic thinking in adult learning education. International Journal of Lifelong Education, 34 (1), 22-31. [in English].

UIE. (1997). Adult Education. The Hamburg Declaration. The agenda for the future. Hamburg: UNESCO Institute for Education. [in English].

UIL. (2009). CONFINTEA VI: Belem framework for action. Harnessing the power and potential of adult learning and education for a viable future (BFA). Hamburg: UNESCO Institute for Lifelong Leaning. [in English].

UIL. (2010). The Sixth International Conference on Adult Education (CONFINTEA VI ) "Living and learning for a viable future: the power of adult learning": Final Report. Hamburg: UNESCO Institute for Education. [in English].

UIL. (2016). The third Global Report on Adult Learning and Education (GRALE III). Hamburg: UNESCO Institute for Lifelong Learning. [in English].

UIL. (2019). 4 Global Report on Adult Learning and Education: Leave no One Behind: Participation, Equity and Inclusion. Hamburg: UNESCO Institute for for Lifelong Learning. [in English].

UNESCO. (1976). Recommendation on the development of adult education. Nairobi: UNESCO, 13. [in English]. 